retention of precursor cells by the bone marrow is regulated. This case suggests that future experiments using steroid administration and withdrawal may help in their elucidation.

\section{References}

Athens, J.W., HaAb, O.P., RaAb, S.O., Mauer, A.M., Ashenbrucker, H., Cartwright, G.E. \& Wintrobe, M.M. (1961) Leukokinetic studies. IV. The total blood, circulating and marginal granulocyte pools and the granulocyte turnover rate in normal subjects. Journal of Clinical Investigation, 40, 989.

Bishop, C.R., Athens, J.W., Boggs, D.R., WARner, H.R., Cartwright, G.E. \& Wintrobe, M.M. (1968) Leukokinetic studies. XIII. A non-steady state kinetic evaluation of the mechanism of cortisone-induced granulocytosis. Journal of Clinical Investigation, 47, 249.

BurketT, L.L., Cox, M.L. \& FieldS, M.L. (1965) Leucoerythroblastosis in the adult. The American Journal of Clinical Pathology, 44, 494.

de Vere, R. \& Bradley, W.G. (1975) Polymyositis: its presentation, morbidity and mortality. Brain, 98, 637.
Glader, B.E., Rambach, W.A. \& Alt, H.L. (1968) Obser vations on the effect of testosterone and hydrocortisone on erythropoiesis. Annals of the New York Academy of Sciences, 149, 383.

Kleeman, C.R., Koplowitz, J., Maxwell, M.H., Cutler, R. \& Dowling, J.T. (1960) Mechanisms of impaired water excretion in adrenal and pituitary insufficiency. Journal of Clinical Investigation, 39, 1472.

Mulder, D.W., WinkelmanN, R.K., Lambert, E.H., Diessner, G.R. \& Howard, F.M. (1963) Steroid therapy in patients with polymyositis and dermatomyositis. Annals of Internal Medicine, 58, 969.

Peschle, C., Marone, G., Genovese, A., Sacchetti, L. \& Condorelli, M. (1974) The hormonal influences on red cell production: physiological significance and mechanism of action. Erythropoiesis. In: Proceedings of the Fourth International Conference on Erythropoiesis, p. 99. University Park Press, Tokyo.

Retief, F.P. (1964) Leuco-erythroblastosis in the adult. Lancet, i, 639.

Weick, J.K., Hagedorn, A.B. \& Linman, J.W. (1974) Leuco-erythroblastosis. Proceedings. Mayo Clinic, 49, 110.

\title{
A case of paraparesis due to extramedullary haemopoiesis in HbE-thalassaemia
}

\author{
J. C. L. MihindukulasuriYa* \\ M.D.
}
V. MACHADO* M.D.

\author{
D. Chanmugam* \\ M.D., M.R.C.P.
}

\author{
C. A. SAmarasinghe $\dagger$ \\ M.B., B.S.
}

\author{
P. A. M. KYNOCH \\ *Department of Medicine, Faculty of Medicine, University of Sri Lanka, Colombo Campus, \\ $\dagger$ Neurosurgical Unit, General Hospital Colombo, and ${ }_{\ddagger}$ Department of Clinical Biochemistry, \\ University of Cambridge
}

\section{Summary}

A 24-year-old female with haemoglobin E-thalassaemia who presented with paraparesis of 18 months' duration was found to have spinal extradural extramedullary haemopoietic tissue extending from T4 to T9. Complete neurological recovery followed laminectomy. The importance of prompt diagnosis and treatment, of this unusual complication of extramedullary haemopoiesis, before the spinal cord is irreversibly damaged is stressed.

Correspondence: Dr D. Chanmugam, Department of Medicine, Faculty of Medicine, Colombo 8, Sri Lanka.

\section{Introduction}

Extramedullary haemopoiesis (EMH) occurs as a compensatory phenomenon in diseases of the haemopoietic system such as congenital haemolytic anaemias (Dawson, 1931), myelofibrosis (Close, Taira and Cleaveland, 1958), pernicious anaemia (Lyall, 1935) and infiltrations of the bone marrow with secondary malignancy (Plonskier, 1930). The common sites of occurrence of EMH are liver, spleen, kidneys and lymph nodes, and rarely the paravertebral region of thorax, retroperitoneal tissue, adrenals, pleura, falx cerebri, dura of the skull and spinal canal. 
Congenital haemolytic anaemia especially hereditary spherocytosis and to a lesser extent thalassaemia and sickle-cell anaemia form the commonest causes of EMH. The first case of HbE-thalassaemia associated with EMH was reported by Hanam (1964) and with subsequent histological confirmation (Da Costa, Loh and Hanam, 1974).

Intraspinal EMH has been reported only in very few instances (Close et al., 1958; Marinozzi, 1958; Sorsdahl, Taylor and Noyes, 1964; Gatto, Terrana and Biondi, 1954; Lowman, Bloor and Newcomb, 1963) and this report is probably the first recorded case of intraspinal EMH in association with $\mathrm{HbE}$ thalassaemia.

\section{Case report}

A 24-year-old female presented with insidious onset of numbness, weakness and unsteadiness of both lower limbs of 18 months' duration. The symptoms started in the left leg, and were followed by abdominal distension and weakness of the right leg. There were no symptoms referable to bladder and bowel and she could only walk with difficulty.

Her parents were in good health and there was no consanguinity. The patient was the third in a family of five siblings, the eldest, a brother who was pale and had an abdominal lump, died at the age of 10 years. The second was a healthy sister who has two healthy children; the fourth was a brother who died aged 5 years with pallor and an abdominal lump. The fifth is a healthy brother. The patient has a 5-yearold healthy daughter (Fig. 1).

She was of average build, had a normal facial appearance and was markedly pale. There was no icterus, lymphadenopathy or sternal tenderness. The cardiovascular and respiratory systems were clini-

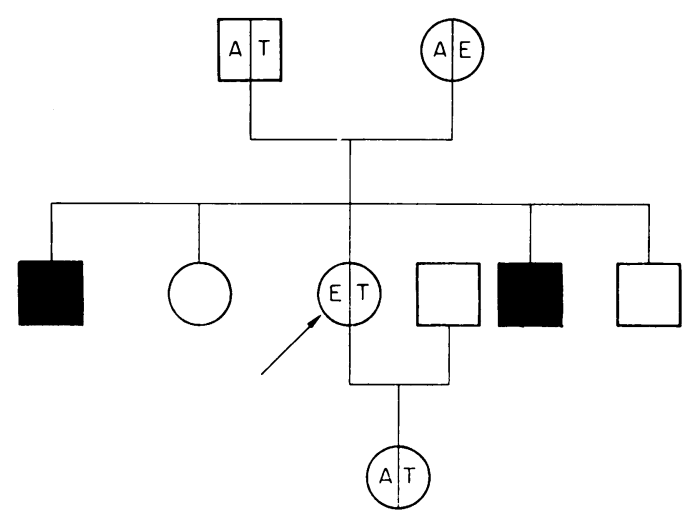

FIG. 1. Family tree with arrow pointing to propositus. AT, $\beta$-thalassaemia trait; AE, HbE trait; ET, HbEthalassaemia. $\square$, $\bigcirc$, untested, thought to be HbAA; $\square$, died of anaemia with jaundice splenomegaly during childhood: thought to have had HbE-thalassaemia. cally normal. The liver and spleen were palpable $4 \mathrm{~cm}$ and $10 \mathrm{~cm}$ below the right and left costal margins respectively.

She was conscious, rational, orientated in time and space. The cranial nerves and upper limbs were normal. There was weakness with spasticity of both lower limbs, more on the left side, which could not be moved against gravity. The muscles of the lower anterior abdominal wall were also weak. The tendon reflexes of both lower limbs were exaggerated and both plantar responses were extensor. The sensation of pain was impaired below the eighth thoracic segment with reduced vibration sense in both lower limbs more on the left side while touch and joint sensations were not altered. There were no cerebellar signs and the gait was spastic.

\section{Investigations}

Urinalysis was normal. Haemoglobin concentration $5 \mathrm{~g} / \mathrm{dl}$. Packed cell volume $0 \cdot 22$; reticulocyte count $5 \%$; WBC $10.4 \times 10^{9} / 1$; neutrophils $33 \%$, lymphocytes $60 \%$; eosinophils $3 \%$ and monocytes $5 \%$. Platelet count $256 \times 10^{9} / 1$; the peripheral blood smear showed marked anisocytosis, poikilocytosis; target cells, punctate basophilia, Howell Jolly bodies, numerous normoblasts and scattered macrocytes; serum bilirubin was $22.2 \mu \mathrm{mol} / \mathrm{l}$. Blood urea 5.8 $\mathrm{mmol} / \mathrm{l}$; aspartate aminotransferase $31 \mathrm{u} . / \mathrm{l}$. Alanine aminotransferase $31 \mathrm{u} . / 1$. Serum proteins $80 \mathrm{~g} / 1$ with albumin $46 \mathrm{~g} / \mathrm{l}$ and globulin $34 \mathrm{~g} / \mathrm{l}$, serum vitamin $B_{1}$ level was $210 \mathrm{ng} / \mathrm{l}$ and serum folate $1.6 \mu \mathrm{g} / \mathrm{l}$.

Her haemoglobin on electrophoresis contained haemoglobins $E, F, A$ and $A_{2}\left(E+A_{2}, 65 \%\right.$; F, $22 \%$; A, $12 \%$ ). Her daughter had $5.9 \% \mathrm{HbA}_{2}$ ( $\beta$ thalassaemia trait) and $2.9 \% \mathrm{HbF}$. Her father also had $\beta$ thalassaemia trait $\left(\mathrm{HbA}_{2}, 5.5 \% ; \mathrm{HbF}, 0.8 \%\right)$ whilst her mother had $\mathrm{HbE}$ trait (HbA, 68\%; $\mathrm{HbF}, 0.8 \%$; $\mathrm{HbE}+\mathrm{A}_{2}, 30.5 \%$ ). The family tree is shown in Fig. 1.

Radiological examination of the chest revealed a normal heart shadow with clear lung fields. There were well defined multiple paravertebral shadows (Fig. 2). The thoracic and lumbar spine was normal. Radio-opaque shadows suggestive of gall stones were seen in the right hypochondrium.

Lumbar puncture revealed a clear CSF with proteins $0.65 \mathrm{~g} / 1$, chlorides $115 \mathrm{mmol} / 1$, sugar $5.3 \mathrm{mmol} / 1$, cells one polymorph with no lymphocytes. The CSF $B_{12}$ was $40 \mathrm{ng} / \mathrm{l}$ by radioimmunoassay.

Myelogram showed a complete block at D9 with a suggestion of extramedullary compression (Fig. 3).

At dorsal laminectomy a highly vascular reddish extradural mass not attached to bone or nerve roots was seen extending from D4-D9 on the posterior and lateral aspects of the spinal cord especially on the left side. The extradural venous plexus was hypertrophied. Complete macroscopic removal was 


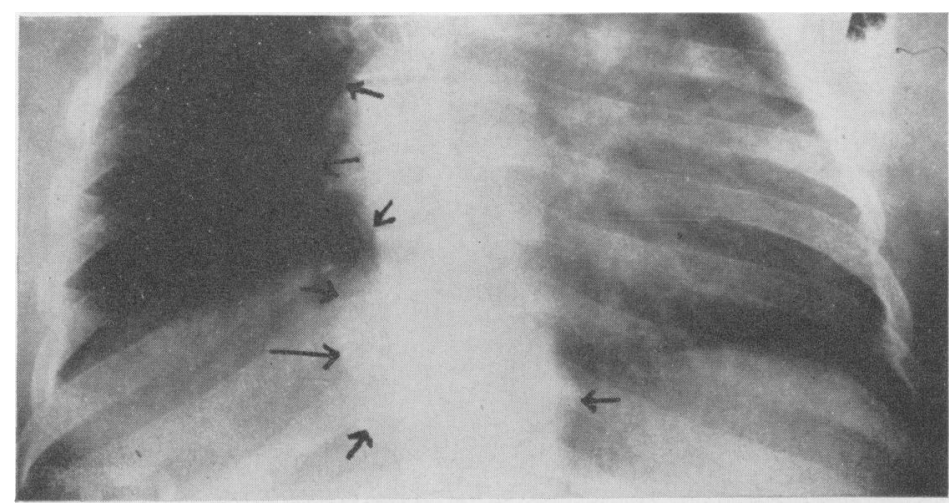

FIG. 2. Radiograph of the thoracic spine with arrows pointing to right upper and lower and left paravertebral shadows.

affected. Severe postoperative bleeding occurred from the venous plexus for which she was transfused with 4 pints of blood. The patient made an uneventful recovery with a dramatic improvement in the power of the limbs so that she was ambulant on the twelfth postoperative day and discharged from

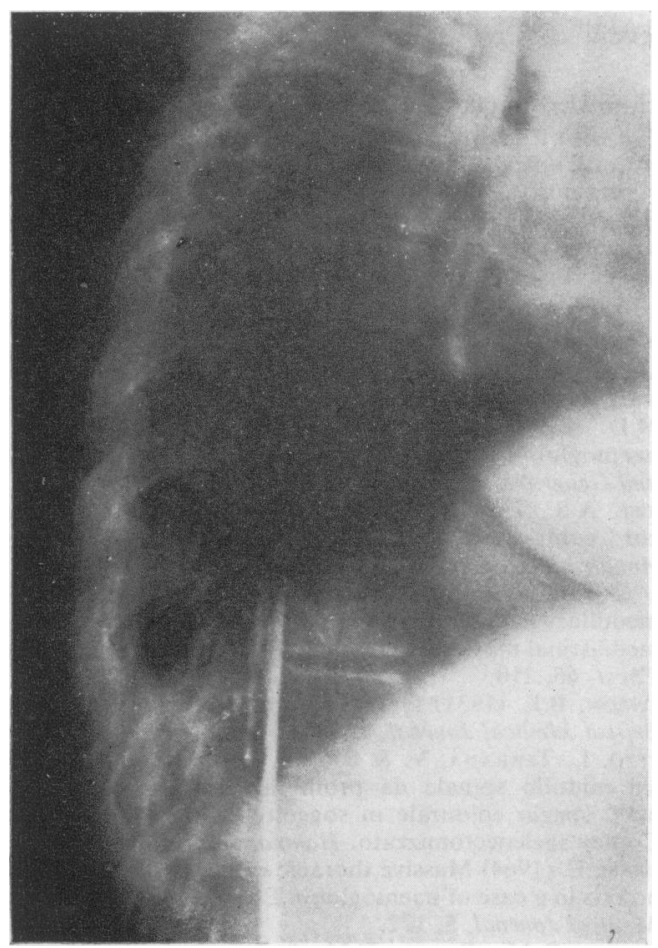

Fig. 3. Lateral view of myelogram showing a complete block at D9 caused by extramedullary compression. hospital, walking confidently, on the thirtieth postoperative day.

Histological examination of the tumour showed an encapsulated mass of haemopoietic tissue consisting mainly of erythroid elements but also with myeloid cells and megakaryocytes (Fig. 4). Laminae showed hyperplastic bone marrow in numerous marrow spaces.

\section{Discussion}

The diagnosis of HbE-thalassaemia in this patient is supported by the family history which also shows the severity of the disorder with the death of two siblings. HbE disease is common in South-East Asia including Sri Lanka (Blackwell et al., 1974).

The occurrence of EMH within the spinal canal is extremely rare and the authors were able to trace only five reported cases in the literature of which only four had clinical evidence of spinal cord compression. Gatto et al. in 1954 reported a 26-year-old thalassaemic patient with spinal cord compression who failed to improve after surgical decompression but had almost complete recovery after irradiation. Marrinozzi (1958) described post-mortem findings of nodular masses of haemopoietic tissue in the spinal epidural spaces from T8-T12 in a 4-year-old girl with thalassaemia. Close et al. in 1958 described a 60-yearold patient with myelofibrosis who presented with symptoms of spinal cord compression of 9 months' duration due to intraspinal EMH tissue but who failed to benefit from surgical decompression or subsequent irradiation perhaps owing to irreparable cord damage which had already occurred.

Lowman et al. in 1963 described a 31-year-old patient with myelofibrosis who had spastic paraparesis with a sensory level due to epidural haemopoietic tissue at D6. This patient partially recovered 


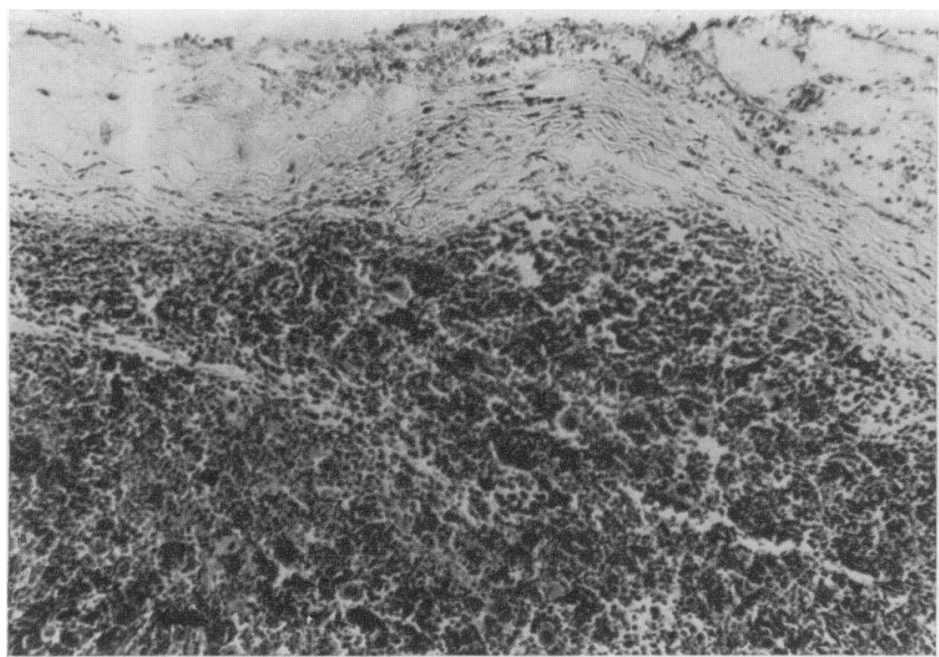

FIG. 4. Photomicrograph $(\times 90)$ of a section of the extradural tissue showing haemopoietic tissue surrounded by a well defined capsule.

after decompression and subsequent irradiation. Sorsdahl et al. (1964) reported a 40-year-old patient with thalassaemia intermedia who had a posterior mediastinal mass with spinal epidural extension from D5 to D10, with severe spinal cord compression, and who too recovered dramatically after surgery. In that patient, as in the present patient, the presence of posterior mediastinal paravertebral masses not only gave a clue as to the cause of the spinal cord compression but also corresponded to the level of spinal extradural EMH tissue.

An unexplained feature noticed in reviewing the paravertebral and intraspinal EMH is the predilection for the mid and lower thoracic regions of the spine. The mode of origin of EMH tissue in the spinal canal is not known. Sorsdahl et al. (1964) suggested that these may arise from primitive tissue laid down in a segmental pattern in association with development of the spinal cord whereas Lyall (1935) considered the tissue to be an extension from the adjacent vertebral bone marrow. In the present patient the mass was encapsulated and not attached to the bone and this would favour the former explanation.

EMH is generally considered to be a compensatory phenomenon in haemolytic states but the occurrence of megakaryocytes and cells of the myeloid series in this tissue is rather enigmatic.

Although rare, the occurrence of extradural EMH should be considered in cases of spinal cord compression occurring in diseases where EMH is likely to occur especially when there is radiological evi- dence of paravertebral masses in the thoracic region. Early diagnosis and prompt treatment are importang if irreversible damage to the spinal cord is to prevented.

\section{Acknowledgments}

We wish to thank Professor H. Lehmann, F.R.S., Depart - ֻّ ment of Clinical Biochemistry, University of Cambridge, for $\frac{2}{\mathbb{D}}$ carrying out the haemoglobin studies; Mr Shelton Cabraal, $\varrho$ F.R.C.S., Senior Neurosurgeon, General Hospital, Colombo, $\overrightarrow{\vec{\theta}}$ who performed the surgery on this patient and Miss $M .3$ Dullewe for her, invaluable help in preparifig this paper.

\section{References}

Blackwell, R.D., Soysa, P.E., De Silva, W.A.S., Nagaratnam, N., Warnasuriya, N., Aberyatne, D.D., Ogren, N.D. \& WoNG, M.I. (1974) Structural identification of haemoglobin E in ethnic groups from Sri Lanka. Tropical and Geographical Medicine, 26, 214.

Close, A.S., Taira, Y. \& Cleaveland, D.A. (1958) Spinal cord compression due to extramedullary haematopoiesis. Annals of Internal Medicine, 48, 421.

Da Costa, J.L., LoH, Y.S. \& HaNam, E. (1974) Extramedullary haemopoiesis with multiple tumour-simulating mediastinal masses in haemoglobin E-thalassaemia disease. Chest, 65, 210.

DAwson, B.E. (1931) Hume lectures on haemolytic icterus. British Medical Journal, 1, 963.

Gatto, I., Terrana, V. \& Biondi, L. (1954) Compressione N sul midollo spinale da proliferazione di midollo osseo nello spazio epidurale in soggetto affetto da malattia di Cooley spelenectomizzato. Haematologica, 38, 61 .

HANAM, E. (1964) Massive thoracic extramedullary haematopoiesis in a case of haemoglobin E-thalassaemia. Singapore Medical Journal, 5, 122.

Lowman, R.M., Bloor, C.M. \& Newcomb, A.W. (1963) Roentgen manifestations of thoracic extramedullary haematopoiesis. Diseases of the Chest, 44, 154. 
Lyall, A. (1935) Massive extramedullary bone marrow formation in a case of pernicious anaemia. Journal of Pathology and Bacteriology, 41, 469.

MARINOZZI, V. (1958) Aspetti insoliti dell'iperplasia midollare nelle anemie emolitiche. Haematologica, 43, 737.

Plonskier, M. (1930) Über tumorformige (extramedullare heterotope) subpleurale Knochenmarksherde. Virchows
Archiv für pathologische Anatomie und Physiologie und fïr klinische Medizin. Berlin, 277, 804.

SORSDAHL, O.S., TAyloR, P.E. \& Noyes, W.D. (1964) Extramedullary hematopoiesis, mediastinal masses and spinal cord compression. Journal of the American Medical Association, 189, 343.

Postgraduate Medical Journal (July 1977) 53, 397-399.

\section{A case of Bacillus cereus bacteraemia}

\author{
M. BARNHAM \\ M.B. B.S.
}

\author{
A. J. TAYLOR \\ M.Sc., F.I.M.L.S.
}

Department of Diagnostic Bacteriology, St Mary's Hospital Medical School, London, W2

\begin{abstract}
Summary
A case is presented of Bacillus cereus bacteraemia in a patient receiving hepatic perfusion with 5-fluorouracil (5FU) for metastasis from a carcinoma of the breast. The literature concerning systemic $B$. cereus infections is briefly reviewed.
\end{abstract}

\section{Case report}

In May 1974, a 66-year-old woman underwent local excision for a poorly differentiated polygonalcell carcinoma of the left breast. She also had a right-sided malignant pleural effusion which was treated with stilboestrol and local instillation of mepacrine. In December 1974, she suffered a local recurrence of the tumour in the breast and was treated with a course of radiotherapy.

In August 1975, the patient was readmitted complaining of tiredness, anorexia and loss of weight. Examination revealed an enlarged liver, three fingers breadth below the costal margin. Investigations showed $\mathrm{Hb} 13.2 \mathrm{~g} / \mathrm{dl}$; WBC $7.5 \times 10^{\circ} / 1$; plasma proteins $64 \mathrm{~g} / \mathrm{l}$; bilirubin $71 \mu \mathrm{mol} / \mathrm{l}$ (normal 5-17 $\mu \mathrm{mol} / \mathrm{l}$ ); alkaline phosphatase 320 u./l (normal 20-95 u./l); aspartate transaminase $76 \mathrm{u} . / 1$ (normal 4-17 u./l) and blood glucose $4.9 \mathrm{mmol} / \mathrm{l}$. A liver scan revealed multiple hepatic secondary deposits; a radiographic skeletal survey showed no evidence of metastasis to bone.

On 11 August, laparotomy was performed and a cannula was inserted into the hepatic artery; multiple hepatic secondary deposits were confirmed by biopsy. After the operation she was treated with $750 \mathrm{mg} 5$-fluorouracil instilled through the cannula by slow injection once a week; the cannula was flushed with $1 \mathrm{ml}$ of a $1: 1000$ solution of heparin twice a day. The site around the cannula remained clean, with swabs yielding no bacterial growth until 1 September, when a serous fluid began to leak from around the cannula and a swab yielded a moderate growth of $B$. cereus and Staphylococcus albus. Paracentesis was performed and a small quantity of ascitic fluid withdrawn, but culture yielded no bacterial growth. On the following day, a blood culture was taken from an arm vein and after $18 \mathrm{hr}$ incubation this yielded $B$. cereus from two of three bottles. $B$. cereus was again isolated from the cannula site on 4 September, although a Gram film showed only scanty polymorphs and the site was clinically improved. The site was found still to be colonized with B. cereus 12 days later. Further blood cultures were taken but the organism was not recovered again.

Throughout this episode, the patient remained well and apyrexial and she required no antibiotic therapy. Associated with the infection was a transient rise in blood glucose $(11.3 \mathrm{mmol} / \mathrm{l}$ on 1 September) and a neutrophil leucocytosis reaching a peak WBC of $17.5 \times 10^{9} / 1$ a few days after the isolation from the blood culture.

Doses of 5-fluorouracil had been administered through the cannula on 29 August and 5 September.

The isolates of $B$. cereus were identified using the methods described by Gilbert and Taylor (1976) and were typed as serotype 2 with the flagella antigen scheme of Taylor and Gilbert (1975). The bacteria showed a typical susceptibility pattern, being sensitive in vitro to neomycin, gentamicin, kanamycin, tetracycline and clindamycin; moderately sensitive to erythromycin and resistant to ampicillin, penicillin, methicillin, cephaloridine and sulphamethoxazole. 